\title{
ArcheoSciences
}

Revue d'archéométrie

Authentication and analysis of goldwork

\section{Wands in the hand! Or Potter's powers}

Une baguette magique dans la main! Ou les pouvoirs de Potter

\section{Alicia Perea}

\section{OpenEdition}

\section{Journals}

Electronic version

URL: http://journals.openedition.org/archeosciences/1906

DOI: 10.4000/archeosciences. 1906

ISBN: 978-2-7535-1598-7

ISSN: 2104-3728

Publisher

Presses universitaires de Rennes

\section{Printed version}

Date of publication: 31 December 2009

Number of pages: $21-28$

ISBN: 978-2-7535-1181-1

ISSN: $1960-1360$

\section{Electronic reference}

Alicia Perea, «Wands in the hand! Or Potter's powers », ArcheoSciences [Online], 33 | 2009, Online since 09 December 2012, connection on 19 April 2019. URL : http://journals.openedition.org/ archeosciences/1906 ; DOI : 10.4000/archeosciences. 1906 


\title{
Wands in the hand! Or Potter's powers
}

\author{
Une baguette magique dans la main! Ou les pouvoirs de Potter
}

\author{
Alicia PereA*
}

\begin{abstract}
Some reflections on the history of archaeometry addressing more specifically gold metallurgy will help us understand recent trends and achievements in this broad field of research. Interdisciplinarity as a peer dialogue between scientists and historians has encountered some serious difficulties, which, however, are almost completely overcome today. The wide choice of non-destructive analytical techniques available is perhaps the main feature of actual research, and this also means that a great variety of problems can be dealt with and solved. Finally, in the present paper I propose some case studies selected from Project $A u$, the research programme I have been coordinating for more than ten years, and from other researchers and teams with whom I collaborate, in order to illustrate how we can conduct goldwork research. These include the two principal, and unique, Visigothic treasures, from Guarrazar and Torredonjimeno (Spain), and the Braganza brooch, a controversial Iberian fibula, masterpiece of ancient jewellery now on display at the British Museum and presented in Madrid during an exhibition in 2007.
\end{abstract}

Résumé : En ce qui concerne la métallurgie de l'or, quelques réflexions sur l'histoire de l'Archéométrie aideront à comprendre les orientations et les succès de ce large domaine de recherche. L'interdisciplinarité, en tant que dialogue scruté entre scientifiques et historiens, a enduré de sérieuses difficultés qui sont actuellement quasiment surmontées. Le vaste choix de techniques non-destructives d'analyse est peut-être la dominante principale de la recherche, ce qui signifie ainsi qu'une large variété de problèmes peut être traitée et résolue. Enfin, de façon à illustrer comment les recherches sur l'or sont menées, j'exposerai quelques études soit prises dans le cadre du Project Au, programme de recherche que je coordonne depuis plus de dix ans, soit réalisées en collaboration avec d'autres chercheurs et groupes de recherche. J'invoquerai les deux principaux et uniques trésors Visigoths, Guarrazar et Torredonjimeno (Espagne), et la broche de Braganza, une fibule ibérique controversée, chef-d'œuvre de l'orfevrerie antique, conservée actuellement au British Museum et présentée à Madrid lors de l'exposition de 2007.

Keywords: Archaeometry, archaeometallurgy, goldwork, analytical techniques, Europe.

Mots-clés : Archéométrie, archéométallurgie, orfevrerie, techniques d'analyse, Europe.

\section{INTRODUCTION}

A memorable exhibition directed by Mark Jones (1990) at the British Museum in 1990, entitled Fake? The Art of Deception, brought together the worst or best errors made in over two centuries of collecting precious art and archaeological objects, not only by the museum's curators, but by other museums all over the world and private collectors as well. In the catalogue, Jones stated that experts saw what they wanted to see. This does not mean we should get rid of all experts, but of arrogance and most of all... of emotions.

Expertise and validation were traditionally based on three aspects: perception-observation, knowledge-experience, and expectations-emotions. The connoisseur's first contact with the object involved an emotional response, positive or negative, based on his knowledge and experience, but conditioned by his or others' expectations.

*Arqueometal Research Group. Centro de Ciencias Humanas y Sociales. CSIC-Albasanz 26-28, 28037 Madrid-Spain. (alicia.perea@cchs.csic.es) 
Since the advent of instrumental methods for quantitative elemental analysis and powerful observation devices in art and archaeology, the work of experts has relied much more on physical sciences and less on emotions and experience. Moreover, and more importantly, these are difficult times for forgers, or at least for non-expert.

Concerning ancient gold, I have always thought that knowledge, not expectations, and the use of binoculars are sufficient to reach a sensible opinion on most of the issues an object presents regarding its authenticity. If we want to proceed further and are interested in the skills of ancient craftsmen, in how they dealt with temperature, tools and workshops; in how they managed know-how, transmission and innovation; if we want to know where they obtained their raw materials, who paid for them and who paid for their work; to sum up, if we are interested in the society behind the object, rather than the object itself, then we must rely on scientific methods of analysis.

Today, the scientist is presented with a wide choice of non-destructive analytical techniques, depending on the questions he/she wants to answer. Two of them are powerful wands in our hands for gold technology research: electron beam microscope/microprobe (SEM), and ion beam analysis (IBA), which includes PIXE, PIGE and RBS methods (Ferro et al., 2003; 2008; Adriaens et al., 2005; Demortier and Adriaens, 2000). Their power consists of, in the first case, the SEM capability for providing high resolution, high magnification images with spot elemental microanalysis; and, in the second, the IBA's ability to detect light and heavy elements, even in large objects, at atmospheric pressure during irradiation.

Reaching this point has not been an easy task. It represents the result of much effort from many people who sometimes failed, but never gave up. Let us have a look back at this story and throw a quick glance at the future as well.

\section{IN THE BEGINNING ... THERE IS FAILING}

Actual research into ancient goldwork is one of the specialisations within the field of archaeometallurgy and its orientation is primarily archaeometric (Rehren and Pernicka, 2008), that is, based on scientific methods of observation and analysis. This has not been achieved in a straightforward way, or without problems and tensions (Pollard and Bray, 2007). The first major project aimed at the analytical and systematic study of gold production during European Prehistory was initiated more than half a century ago in the context of the programme Studien zu den Anfängen der Metallurgie undertaken by the
Württembergisches Landesmuseum Laboratories, Stuttgart. The results of sampling almost 5,000 gold artefacts from museums all over Europe were published by Hartmann in 1970 and 1982. However, the results did not live up to the expectations generated by the project, either in terms of technology or from the social and economic point of view. The disappointment was followed by a period in which the elemental chemical composition did not form part of the central approach adopted for research into gold (Perea and Armbruster, 2008).

Much has been said about the reasons why this European and international project failed, but they boil down to two major ones: a) a statistical approach unsuitable for analytical data, and b) the absence of an archaeological theoretical basis that would provide a historical frame of reference for the vast quantity of numeric results thrown into disarray by the interpretive statistics themselves (Waterbolk and Butler, 1965; Taylor, 1980). In brief, the selected methodology could not answer the questions raised about the origin of metallurgy and metal exchange in Prehistoric Europe. However, the resulting data are still there, available to any researcher who may be interested and able to interpret them more skilfully (Warner, 2004).

At the same time, as the analytic-scientific approach was running out of steam, the traditional methodology based on typology or style was being lost in treatises on form, aesthetic valuations, and other subjective approaches that betrayed the intellectual legacy of Worsae and Montelius as much as that of Winckelmann. Unrelated with this situation, in a different context, somewhere between archaeology and art, midway between the academic world and that of museums, in restoration laboratories and gold workshops, archaeologists and historians were building up a corpus of knowledge on traditional gold working processes based on the observation of artefacts, craftsmen's practices, and knowledge regarding the technical conditions of the historical period under consideration.

One of the pioneers of this line of research was Herbert Maryon, who published his book Metalwork and Enamelling in 1912, an enormous work which remained in print until 1971. This line of work requires experimentation as a method of research into ancient technology. One great such experimenter was Fortunato Pio Castellani (1794-1865), founder of the Archaeological School of Jewellery in the mid$19^{\text {th }}$ century, followed by his sons Augusto and Alessandro (Castellani, 1861), who were astonished by the skill and difficulty of ancient gold working techniques, although some would prefer to describe them as great tricksters. However, that is another story (Bury, 1975; Munn, 1981; 1983). 


\section{THE PRODigious DECADE}

Between 1980 and 1990, the panorama changed radically in almost all European countries, where research on metalwork incorporated archaeometry, that is the application of scientific methods of identification, measurement and quantification of the archaeological and historical heritage, with the aim of interpreting, dating, observing, restoring and displaying that heritage to a public that was becoming increasingly interested in its past. In my opinion, two fundamental causes were responsible for the new situation. Firstly, it was the empiricist, or, better said, objectualist trend that favoured archaeological practices whose paradigm was to achieve objectivity: archaeometric data would thus be the only unquestionable data as far as postmodern research is concerned. Secondly, new, non-destructive analytical methods were refined and became increasingly powerful, precise, inexpensive and accessible, and others were adapted to the needs of a material with a high intrinsic and museum value. For example, the development of portable X-ray fluorescence (XRF) equipment led to an exponential growth of the number of metal objects analysed before and after 1980 . During this same stage, lead isotope ratio analysis began to be offered for copper-based alloys, which, together with the analysis of trace element patterns, made it possible to begin investigating the mineral's provenance (Gale and Stos-Gale, 1982), opening up the possibility of proposing interpretive models for the circulation and exchange of raw materials. It has been a long and strange trip indeed... (Pollard, 2009).

As with all aspects of research, funding is the determining factor for ensuring the health and future of a line of research. Along these lines, the policy adopted by the United Kingdom since the 1990s in endowing archaeometry with special funding is significant, and explains its current world leadership in this field (Killick, 2008).

Recent bibliometric studies (López-Romero and MonteroRuíz, 2006; Costa Caramé, 2008) have shown that the elemental analysis technique most used in archaeometallurgical research since the mid-1980s has been electron microscopy (SEM), accounting for $25.9 \%$ of the ten techniques considered (Fig. 1). Occupying the second place is X-ray fluorescence (XRF) with $20.0 \%$. Another technique that particularly interests us is particle induced $\mathrm{X}$-ray emission (PIXE): the percentage of its use among the techniques considered is only $5.5 \%$ over the same period, but, considering its high cost and the complex infrastructure required, this is not an unimpressive figure.

In the case of gold, the current trend has led, as in other areas of archaeometallurgy, to the combination of various analytical techniques and modes of observation not only

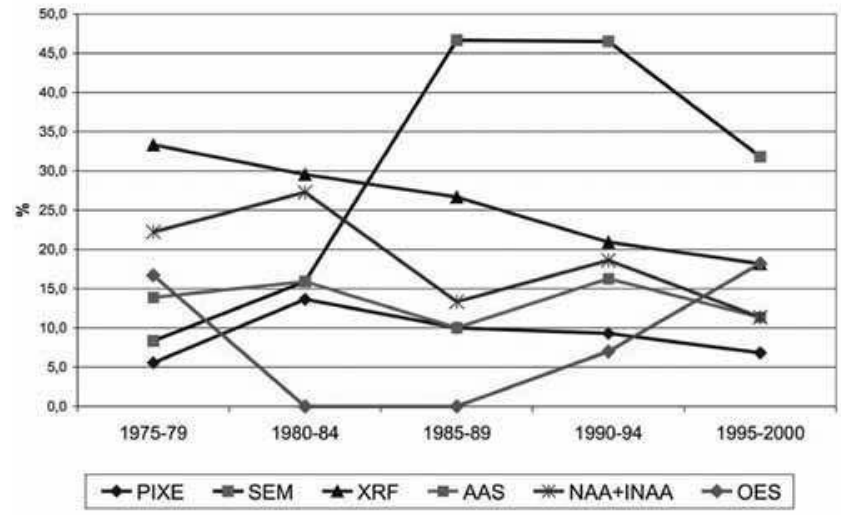

Figure 1: The most frequently used elemental analysis techniques (based on López-Romero and Montero-Ruíz, 2006).

Figure 1 : Les techniques d'analyse les plus rependues (d'après LópezRomero et Montero-Ruiz, 2006).

as methods of control and evaluation, but as ways of responding to the many questions raised by an ancient artefact: when it was made, how, why, by whom and for whom: in short, its life history and present destiny (Gosden and Marshall, 1999). It thus appears necessary to go back to the artefact, because it contains all the technological information, and, in its context, all the symbolic and ideological information pertaining to it. However, this process is not without problems. The greatest difficulty that has been detected in the course of these years is the dialogue between the archaeological scientist, on one hand, and the archaeological historian or anthropologist, on the other (Jones, 2004). However, this is, in my opinion, a question of perspective rather than a real problem, which is expressed by resorting to the old duality of materiality versus meaning, object versus subject.

\section{ToDAY}

The study of a gold artefact should not be an isolated and anecdotal event. There is no point in using the most powerful and sophisticated analytical technique available if we are unable to set the artefact in its socio-technological context - society explains technology as much as the technology explains society. In order to achieve this, planning and method are important, because materiality cannot be investigated stripped of its meaning, at least not in historical terms.

At present, we can no longer conceive of research without a prior methodological approach that does not fulfil one of the following conditions: systematic / interdisciplinary / 
experimental. These tools ensure a greater prospect of success when confronting the problems presented by gold, even with its exceptional character, because in our field of study the exceptional is usually the norm.

I should like to present two cases that have posed very different problems for research. In both these cases, finding the solution has involved turning to the knowledge and experience of other researchers and experts, and to instrumental techniques of observation and analysis. The human factor can never be replaced by technology.

\section{THE CASE OF VISIgOTH GOLDWORK: GUARRAZAR AND TORREDONJIMENO}

The Visigoths reached the Iberian Peninsula in 418 and founded a Hispanic Kingdom that lasted until 711. At that time, within a year, the devastating Islamic invasion launched from Jebel al-Tarik (Gibraltar) and took over the major cities, including Toledo, the capital of the Visigoth Kingdom. This led to destruction and plunder. Only two treasures, hidden before the imminent Arab invasion, remain of the ancient splendour of the Visigoth court and church, which had adopted the Byzantine rite. One was found in Guarrazar, near Toledo, and the other in Torredonjimeno, near Jaén. Both consisted of crowns and crosses that kings, courtiers and eminent dignitaries offered to certain churches in order to obtain divine favour and demonstrate their temporal power to human subjects - among them, the famous crown of King Reccesuinth (653-672).

The Guarrazar treasure has been divided and is currently on display in various museums in Madrid and Paris, which adds to the difficulty of examining a valuable and unique material. Nevertheless, the assemblage has been studied in a systematic and interdisciplinary way. The entire collection, consisting of ten crowns and eight crosses (Fig. 2), was analysed using PIXE, since we thought this effort was justified in view of our lack of knowledge of the processes of Visigoth manufacture and raw materials. At that time, there was no particle accelerator with an external beam in Spain, so we had to obtain European funding for this project. With the help of two COST Actions, in 1997 and 1999, we gained access first to the LARN (Laboratoire d'Analyses par Réactions Nucleaires) in Namur (Belgium), to analyse a series of samples that had been taken from the part of the treasure kept in the Museo Arqueológico Nacional, Madrid, and second, to the AGLAE accelerator of the Centre de Recherche et de Restauration des Musées de France, in the Louvre complex, where all the pieces kept in the Musée Nationale du Moyen Âge de Cluny (Paris) were analysed using PIXE and PIGE techniques. An inter-

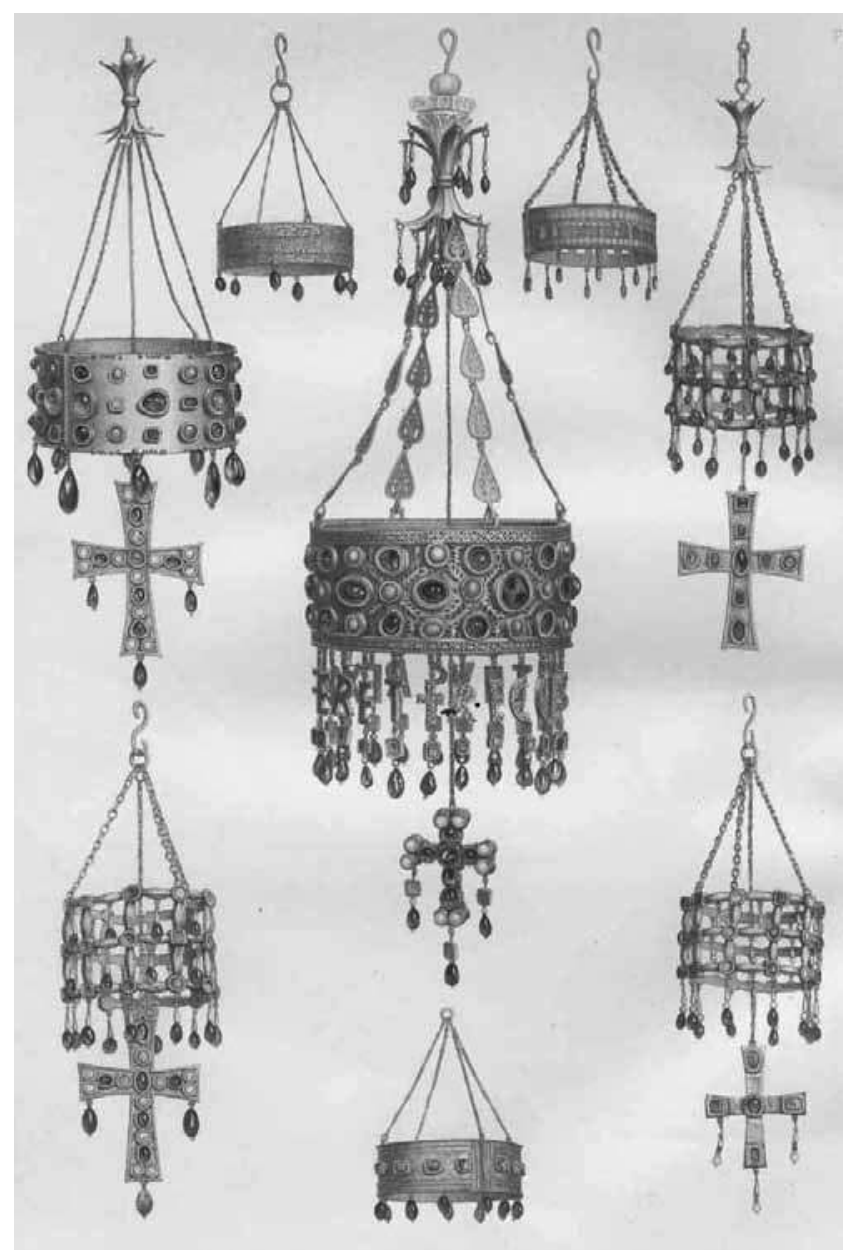

Figure 2: (See colour plate) $19^{\text {th }}$ century illustration of the Guarrazar Treasure (de Lasteyrie du Saillant, 1860).

Figure 2: (Voir planche couleur) Illustration du XIX siècle du trésor de Guarrazar (de Lasteyrie du Saillant, 1860).

disciplinary team subsequently studied the metals, gems and glass, and also the various technical, social, economic and historical aspects pertaining to these objects. The results were published in a monograph (Perea, 2001).

The Guarrazar project was a successful experience of international and interdisciplinary collaboration. It is still opening up new avenues of research: for example, the micro-samples that were extracted from the pieces in the Museo Arqueologico Nacional de Madrid to be analysed in Namur were subsequently re-analysed in Paris, modifying the previous conditions. The aim was to detect the trace elements in order to determine the provenance of the gold (Guerra et al., 2004; 2007).

The second phase of this research project, in 2004, consisted of analysing the Torredonjimeno treasure, which is also distributed among three museums in different Spanish cities: 
Barcelona, Cordoba and Madrid. This treasure contained royal crowns and votive crosses, like the previous one, but it was in very poor condition. Most of the pieces had been broken up, the royal crowns had disappeared, and we only knew they had existed from the letters that had hung from the dia$\mathrm{dem}$, as in the case of the Reccesuinth crown. At first glance, the gold appeared to consist of alloys with very low purity, and containing pieces made directly from silver. In addition to the terrible fragmentation of the crosses, some restoration work had damaged the pieces even more (Fig. 3a, b).
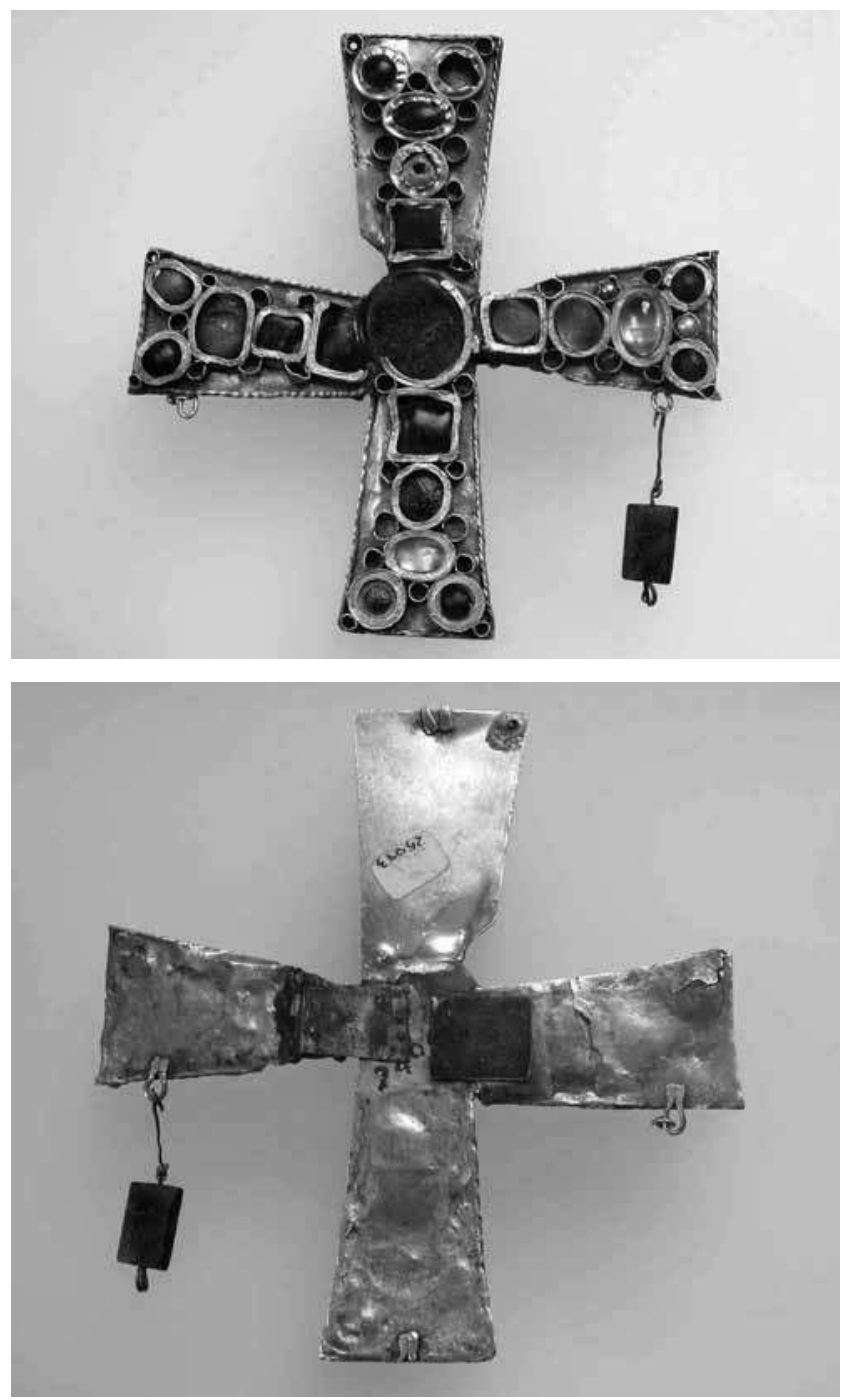

Figure 3a, b: (See colour plate) The cross MAC 25093 from the Torredonjimeno Treasure, made up of at least two different fragmented objects (a), and the arrangement as seen from the back (b) (Photograph by Archivo Au, O. García-Vuelta).

Figure 3a, b : (Voir planche couleur) La croix MAC 25093 du trésor de Torredonjimeno, constituée de fragments d'au moins deux objets différents (a), et leur disposition à l'arrière (b). (Photographie par l'Archivo Au, O. Garcia-Vuelta).
In view of the impossibility of analysing almost two hundred pieces or fragments, a sampling of 29 objects was carried out, and these were analysed by PIXE and PIGE in the Tandetron accelerator of the Centro de Microanálisis de Materiales of the Universidad Autónoma de Madrid, which by this time had an external beam. On this occasion, we found to our surprise that most of the pieces were not made of gold, but of silver gilded with a mercury amalgam, an aspect that had not been detected in the entire history of research on this collection since it was discovered in 1926.

Once again, an interdisciplinary team studied the various archaeometric and historical aspects pertaining to the artefacts. The result was a second monographic volume, recently published (Perea, 2009), which completes the series on Visigoth goldwork in Spain.

\section{The case of the Braganza Brooch, OR AN EXCEPTIONAL PIECE}

Let us leave aside the great treasures in order to discuss the small, exceptional and unique. The case of the Braganza Brooch is one of them (Fig. 4).

This fibula, $14 \mathrm{~cm}$ long, made in gold and enamel, has a long history behind it, not just because it dates to a period around the $4^{\text {th }}-3^{\text {rd }}$ century $\mathrm{BC}$, but also because of its bizarre contemporary history, once being in the possession of the Portuguese Royal House of Braganza at some point in the $19^{\text {th }}$ century. But that is another story, for which there is no space in the present paper. The period that concerns us begins in 2001, when the British Museum purchased this jewel in the Christie auction of 25 April. Although perhaps it is better to begin the story around 1956, when one of its for-

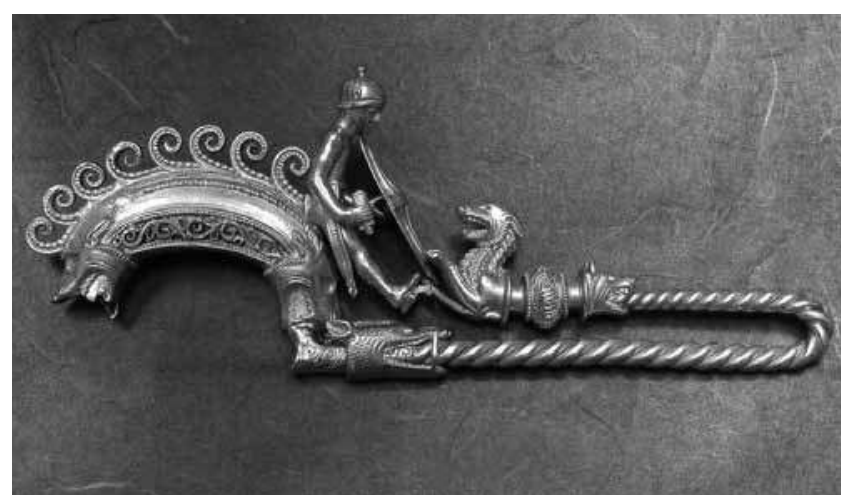

Figure 4: (See colour plate) The Braganza Brooch (The British Museum. Photograph by Archivo Au, A. Perea).

Figure 4: (Voir planche couleur) La broche de Braganza (The British Museum. Photographie par l'Archivo Au, A. Perea). 
mer owners sent some photographs to the British Museum in order for them to get an idea of what he actually had in his collection... and it is at this point that a controversy, which for some people has still not been resolved, ensued.

At that time, Bernard Ashmole did not consider it to be an original ancient work. For his part, Paul Jacobsthal completely disagreed and thought it was "easily one of the most exciting antiques I have come across". From that time onward, the most varied opinions concerning this piece succeeded each other, limited however to the academic world. In spite of this, in the Iberian Peninsula, its place of origin, these debates passed completely unnoticed.

We then had to wait until 1993, when the Braganza Brooch was deposited in the British Museum on loan and was submitted to an exhaustive study that confirmed, firstly, its age, and secondly, that nothing, ancient or modern, had been added to it. This model study, carried out by Ian Stead and Nigel Meeks (1996), is based on the observation of work traces using an optical microscope and a scanning electron microscope (SEM). In order to characterise the material, an elemental analysis was undertaken using a combination of X-ray fluorescence and EDX analysis in the SEM. The enamel was analysed by X-ray diffraction in order to identify the opacifier and by SEM/EDX for composition and colorants. The results brought to an end an absurd controversy based solely on ignorance and prejudice in response to an exceptional object.

In 2007, with the help of a collaboration with the British Museum in the person of Dyfri Williams, the Braganza Brooch came to Spain - most probably its place of origin to be presented to the Spanish public, who never before had the opportunity to admire it (Perea et al., 2007). This seemed to me a unique opportunity to organise a small symposium for scientific discussion among specialists (Perea, in press). We can now state with certainty that the brooch belongs to a very special type of Iberian 'bent-back foot' fibulae made in gilded silver, which usually depict hunting scenes. It was probably offered to an Iberian sanctuary by the prince who ordered it for a special occasion. It also became clear that the goldsmith who made it was an exceptional artist, whose eye was familiar with the Hellenistic aesthetics of the time, and was very probably of Greek origin. However, uncertainties and disagreements regarding this object still remain, mainly related to the iconographic interpretation of the scene depicted on it.

\section{AND THE FUTURE?...}

I do not think the immediate future holds major surprises, although new avenues of research are still being inaugurated, mainly in two fields: studies looking at the provenance of the gold, and methods of dating.

Concerning the provenance of gold, much work has been carried out in this direction and good results produced by characterising trace element patterns (Guerra et al., 1999). The most frequently used techniques are inductively coupled plasma mass spectrometry (ICP-MS) and proton activation analysis. However, there is still a need to characterise natural gold, despite the work that has been undertaken, particularly in Ireland, where the study of gold has traditionally been a topic of 'national interest' (Chapman et al., 2006). Other recent research has centred on the analysis of osmium isotope ratios for those samples of gold that display metal inclusions belonging to the platinum group (Junk and Pernicka, 2003); lead isotope signatures have been used for $\mathrm{Au}-\mathrm{Ag}-\mathrm{Cu}$ alloys with a gold content of more than $70 \%$ (Bendall et al., 2009). Both systems have been used to study coins. This approach suffers from the same aforementioned problem of a lack of natural gold references.

With regard to the methods of dating, experiments are currently being undertaken with the Uranium/ThoriumHelium content of gold in order to detect fakes, although the technique is still in the experimental stage (Eugster $e t$ al., 2008; 2009).

Scientific methods for investigating gold, like any other metal, are now essential for a serious examination of its history and meaning. However, we cannot solve all the problems or answer all the questions with analytical techniques alone. As in the story of Harry Potter, the magic wand never works if it is not in the hands of the right person. The one Potter chose measured eleven inches and was made of holly and phoenix feather (Rowling, 1998: 65).

\section{Note}

This work is part of a research project entitled "Grounds for an Archaeometric and Technomic Research on Metallurgy during Prehistory and Antiquity. The Iberian Peninsula" (Ref.: HUM2006-06250/HIST) within the Programme CONSOLIDER INGENIO 2010 (CSD-TCP), funded by the Ministry of Science and Innovation, Spain.

\section{References}

Adriaens, A., Degrigny, C. and Cassar, J. (eds.), 2005. Benefits of non-destructive analytical techniques for conservation. Papers from a COST Action G8 workshop held in Kalkara, Malta, on 8 January 2004. Luxembourg, Office for Official Publications of the European Communities. 
Bendall, C., Wigg-Wolf, D., Lahaye, Y., Von Kaenel, H.M. and Brey, G.P., 2009. Detecting changes of Celtic gold sources through the application of trace element and $\mathrm{Pb}$ isotope laser ablation analysis of Celtic gold coins. Archaeometry 51(4): 598-625.

Bury, S., 1975. Alessandro Castellani and the revival of granulation. Burlington Magazine 117(871): 664-668.

Castellani, A., 1861. A memoir on the art of the goldsmith in Ancient Times. The Archaeological Journal 18: 365-368.

Chapman, R.J., Leake, R.C., Warner, R., Cahill, M., Moles, N.ÇR., Shell, C. and Taylor, J.J., 2006. Microchemical characterisation of natural gold and artifact gold as a tool for provenancing prehistoric gold artefacts: a case study in Ireland. Applied Geochemistry 21: 904-918.

Costa Caramé, M.E., 2008. Estado actual de la investigación arqueometalúrgica en España: una aproximación bibliométrica, in S. Rovira Llorens, J. García-Heras, M. Gener Moret, I. Montero-Ruiz (eds.), Actas VII Congreso Ibérico de Arqueometría (Madrid, 8-10 October 2007). Madrid, CSIC, 398-409.

Demortier, G. and Adriaens, A. (eds.), 2000. Ion beam study of art and archaeological objects. A contribution by members of the COST G1 Action. European Community (EUR 19218). Luxembourg, Office for Official Publications of the European Communities.

Eugster, O., Kramers, J. and KrähenbüHL, U., 2008. Detecting forgeries among ancient gold objects using the $\mathrm{U}, \mathrm{Th}-4 \mathrm{He}$ dating method. Archaeometry 50: 1-10.

Eugster, O., Pernicka, E., Brauns, M., Shukolyukov, A., Olive, V. and Roellin, S., 2009. Helium, uranium and thorium analyses of ancient and modern gold objects: estimates of their time of manufacturing. ArcheoSciences 33.

Ferro, D., Formigli, E., Pacini, A. and Tossini, D., 2003. Experimental Archaeology approach to the study of copper salts weldings, in Archaeometallurgy in Europe. Proceedings: International Conference, 24-26 September, 2003, vol. I. Milano, Associazione Italiana di Metallurgia, 305-314.

Ferro, D., Formigli, E., Pacini, A., Tossini, D., 2008. La Saldatura nell'Oreficeria antica. Indagini archeometriche e archeologia sperimentale. Roma, CNR. Edizioni Kappa.

Gale, N.H. and Stos-Gale, Z.A., 1982. Bronze Age copper sources in the Mediterranean. Science 216: 11-19.

Gosden, C. and Marshall, Y., 1999. The cultural biography of objects. World Archaeology 31(2): 169-178.

Guerra, F. and Sarthre, C.O., Gondonneau, A. and Barrandon, J.N., 1999. Precious metals and provenance inquiries using LA-ICP-MS. Journal of Archaeological Science 26: 1101-1110.

Guerra, F., Perea, A. and Calligaro, T., 2004. Coins and crowns. A first approach to the gold characterization of the treasure of Guarrazar (Toledo, Spain), in A. Perea, I. Montero-Ruiz,
O. García-Vuelta (eds.), Tecnología del Oro Antiguo: Europa y América. Madrid, CSIC, 417-422.

Guerra, F., Calligaro, T. and Perea, A., 2007. The treasure of Guarrazar: tracing the gold supplies in the Visigothic Iberian Peninsula. Archaeometry 49(1): 53-74.

Hartmann, A., 1970. Prähistorische Goldfunde aus Europa I. Studien zu den Anfängen der Metallurgie, Band 3. Berlin, Mann.

Hartmann, A., 1982. Prähistorische Goldfunde aus Europa II. Studien zu den Anfängen der Metallurgie, Band 5. Berlin, Mann.

JoNES, A., 2004. Archaeometry and materiality: materials based analysis in theory and practice. Archaeometry 46(3): 327-338.

Jones, M. (ed.), 1990. Fake? The Art of Deception. London: Published for the Trustees of the British Museum by British Museum Publications.

Junk, S.A. and Pernicka, E., 2003. An assessment of osmium isotope ratios as a new tool to determine the provenance of gold with platinum-group metal inclusions. Archaeometry 45(2): 313-331.

KILlick, D., 2008. Archaeological science in the USA and Britain, in A. Sullivan (ed.), Archaeological Concepts for the Study of the Cultural Past. Salt Lake City, University of Utah Press, 40-64.

de Lasteyrie du Saillant, F.-C.-L., 1860. Description du Trésor de Guarrazar. Paris, Gide Éditeur.

López-Romero, E. and Montero-Ruíz, I., 2006. Archaeometry and the international evolution of studies on metallurgy: a bibliometrical perspective, in $34^{\text {th }}$ International Symposium on Archaeometry, Zaragoza (2004). Zaragoza, CSIC, 195-200.

Maryon, H., 1971. Metalwork and Enamelling $\left(5^{\text {th }}\right.$ revised edition). New York, Dover Publications.

MunN, G.C., 1981. Jewels by Castellani. Some sources and techniques examined. The Connoissseur 206(828): 126-131.

Munn, G.C., 1983. Les Bijoutiers Castellani et Giuliano. Retour à l'Antique au XIX siècle. Fribourg, Office du Livre, Éditions Vilo.

Perea, A. (ed.), 2001. El Tesoro Visigodo de Guarrazar. Madrid, CSIC.

Perea, A. (ed.), 2009. El Tesoro visigodo de Torredonjimeno. Madrid, CSIC, Ed. Polifemo.

Perea, A. (ed.), in press. La Fíbula Braganza. Diálogos bilingües en torno a la excepcionalidad. Madrid, Ed. Polifemo

Perea, A. and Armbruster, B., 2008. L'Archéologie de l'or en Europe. Perspective. La revue de l'INHA 1: 29-48.

Perea, A., Williams, D. and Olmos, R., 2007. El Héroe y el Monstruo. Exhibition Catalogue (Museo Arqueológico Nacional, 27 April-29 July). Madrid, Ministerio de Cultura.

PollarD, A.M., 2009. What a long strange trip it's been: Lead isotopes and Archaeology, in A.J. Shortland, I.C. Freestone, Th. 
Rehren (eds.), From Mine to Microscope. Advances in Ancient Technology. Oxford, Oxbow Books.

Pollard, A.M. and Bray, P., 2007. A bicycle made for two? The integration of scientific techniques into archaeological interpretation. Annual Review of Anthropology 36: 245-259.

Rehren, Th. and Pernicka, E., 2008. Coins, artefacts and isotopes. Archaeometallurgy and Archaeometry. Archaeometry 50(2): 232-248.

Rowling, J.K., 1998. Harry Potter and the Philosopher's Stone. London, Bloomsbury.

Stead, I.M. and Meeks, N.D., 1996. The Celtic Warrior Fibula. The Antiquaries Journal 76: 1-16.
TAYlor, J.J., 1980. Bronze Age Goldwork of the British Isles. Cambridge, Cambridge University Press.

WARNER, R., 2004. Irish gold artifacts: observations from Hartmann's analytical data, in H. Roche, E. Grogan, J. Bradley, J. Coles, B. Raftery (eds.), From Megaliths to Metal. Essays in Honour of George Eogan. Oxford, Oxbow Books: 72-82.

Waterbolk, H.T. and Butler, J.J., 1965. Comments on the use of metallurgical analysis in prehistoric studies. Helinium 5: 228-234 